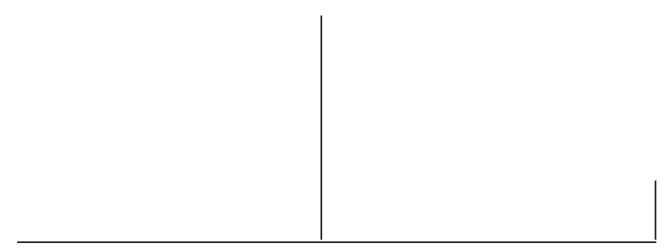

Rev. Latinoam. Psicopat. Fund., IV, 3, 11-26

\title{
A pintura, os desenhos... são imagens que pedem para serem escritas*
}

\author{
Joyce M. Gonçalves Freire \\ Mario Eduardo Costa Pereira
}

\begin{abstract}
A singularidade de uma escuta psicanalítica com pacientes psicóticos exige de quem se dispõe a trabalhar com esses pacientes um despojamento que visa a ultrapassar os limites de uma transferência, à primeira vista, incontornável. É apresentado aqui o manejo transferencial através da escrita de uma paciente psicótica e algumas reflexões sobre a expansão do espaço psicanalítico que a clínica com psicóticos demanda.
\end{abstract}

Palavras-chave: Psicanálise, psicose, transferência, literatura

* Este artigo é parte da pesquisa em mestrado que está em andamento no Departamento de Psicologia Médica e Psiquiatria da Unicamp, sob orientação do Prof. Dr. Mario Eduardo Costa Pereira. 
... as palavras numa página dão coerência ao mundo.

Manguel, 2000: 13

É possível, sob certas circunstâncias e certas peculiaridades, que o ato subjetivo da escrita, e por que não dizer, da arte como um todo - a pintura, a escultura, o desenho e a música - permita, por si só, a criação de um lugar apropriado à alteridade, com certas garantias de que o autor não naufrague ao ouvir o canto da sereia de sua própria ficção. Penso mesmo que isto deva ocorrer com a maioria dos escritores e artistas. Outros tantos vêemse, com certa freqüência, com o fio da navalha a fazer jorrar uma realidade que, a princípio, deveria ser apenas ficção; mas mesmo esses, não sem um enorme esforço que os consome por inteiro, conseguem estancar isso, destinando-lhe o lugar nobre da ficção. Goethe, com seu Werther, talvez seja o exemplo mais emblemático de que temos notícia. Sua escrita o impediu de ter, ele mesmo, o destino de seu personagem. ${ }^{1}$ Outros, nem tanto. A escrita de Hölderlin, a pintura de van Gogh e, contemporaneamente, as magníficas interpretações musicais de Glenn Gold, permeadas por seu aguilhão obsessivo, nada disso os impediram de sucumbirem, de forma peculiar a cada um, ao sofrimento psíquico extremo.

Não é minha intenção, ainda que estreitamente relacionada com questões que logo levantaremos, pensar sobre aqueles que, por assim dizer, deram sorte com sua arte. Também não tenho, nesse momento, a preocupação de estabelecer relações entre a vida e a obra daqueles a quem a arte não foi suficiente para os resgatar daquele mundo muitas vezes assustador e fatal da loucura. Mas essas questões nos levam a navegar pelos mares nem sempre calmos da vida de uma paciente psicótica, cuja sensibilidade a levou ao encontro da escrita e da pintura.

É interessante notar que, por anos a fio, sua escrita teve a marca da solidão; parecia ser endereçada a si mesma e às suas conversas com seus per-

1. Em seu livro de memórias Poesia e verdade (p. 222), escreve: "Foi assim que comecei a seguir essa direção de que nunca mais pude afastar-me: transformar em quadros, em poemas, todos os motivos de minhas alegrias, dores, preocupações, e estabelecer a ordem dentro de mim mesmo, seja a fim de retificar minhas idéias sobre os objetos exteriores, seja para fazer meu espírito voltar ao repouso no tocante a essas coisas. Esse dom me era mais necessário do que a ninguém, uma vez que, por natureza, eu era incessantemente arremessado de um extremo a outro. Assim, pois, tudo que tenho publicado são apenas fragmentos de uma grande confissão, e estas memórias não representam mais que uma aventurosa tentativa de completá-la." 


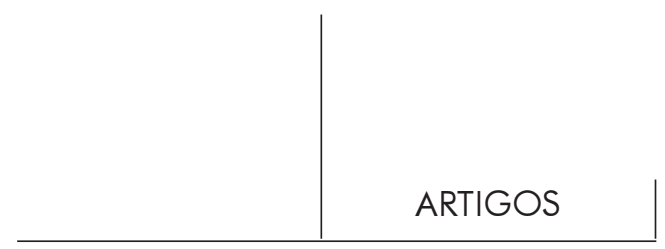

sonagens; não havia um laço que a envolvesse a ponto de buscar um interlocutor externo a si própria. Era, por assim dizer, um solilóquio impresso.

Antes de irromper seus sintomas psicóticos, Lia já vinha, há dois anos, sendo acompanhada pela psiquiatria ${ }^{2}$ e também fizera algumas tentativas de psicoterapia, as quais não foram possíveis levar adiante por sua dificuldade em aderir ao tratamento. Segundo informações obtidas através de seu prontuário, a paciente faltava muito e, nas poucas vezes em que compareceu ao ambulatório, trazia um discurso pobre; pouco falava e, quando o fazia, era de forma pesada e arrastada. Assim, seu tratamento, nessa época, foi basicamente medicamentoso. Nesse primeiro momento, seus sintomas eram de extrema inibição tanto na expressão de suas emoções quanto no contato de relações com as outras pessoas; sentia-se angustiada e muitas vezes muito deprimida, estados esses que a levavam a dormir o dia todo, sendo esta uma das razões de suas faltas às tentativas de psicoterapia. Em razão de seus sintomas, foi diagnosticada, de acordo com o CID-10, como portadora de Fobia Social, cujo diagnóstico determinou, por mais ou menos um ano, o uso do medicamento Parnate.

Durante meu estágio em psicoterapia psicanalítica ${ }^{3}$ (abril de 1996), esta paciente foi agendada para um acompanhamento psicoterápico. Na primeira entrevista, ela se apresenta na sala como "repórter" cujo nome era Estela Vassoler - mais tarde vim a saber que era uma das personagens de um romance que havia escrito e, antes de qualquer outra palavra, pede-me permissão para gravar a entrevista. Eu lhe digo que sim, e ela, vagarosamente, liga um velho gravador na tomada; de tempos em tempos, durante a entrevista - de mão dupla, por assim dizer, pois, efetivamente, era a primeira entrevista que eu fazia com ela e ao mesmo tempo ela me entrevistava, já que era uma "repórter" - voltava a fita, dizia querer ouvir a própria voz e tecia comentários como: “... minha voz é feia, é arrastada; não sei como as pessoas me agüentam". É interessante notar que, como o gravador era muito antigo e ela falava muito baixinho, o que se ouvia eram sons inarticulados como um balbucio. No entanto, ela dizia que precisava ouvir a própria voz. Arrisquei-me em dizer-lhe que parecia escapar de si mesma e a materialidade da gravação de sua voz dava-lhe sustentação: ao ouvir sua voz - sons inarticulados - sentia-se presente. Repetidamente voltava a fita para ouvir o som de sua voz.

Dizia-se sem graça e que não sabia por que estava ali; só ficava interessante quando ela era "a repórter, a jornalista Vassoler: ia atrás do que acontecia na vida, era destemida, conversava com as pessoas sem nenhum pudor, escrevia sobre a vida das pessoas; mas quando volto a ser eu mesma, é a mesma chatice de sempre, sem ne-

2. Ambulatório de Psiquiatria e Ambulatório de Psicoterapia Psicanalítica - Hospital de Clínicas da Unicamp.

3. Estágio em Psicoterapia Psicanalítica, oferecido pelo Laboratório de Psicopatologia Fundamental - Departamento de Saúde Mental - Unicamp. 


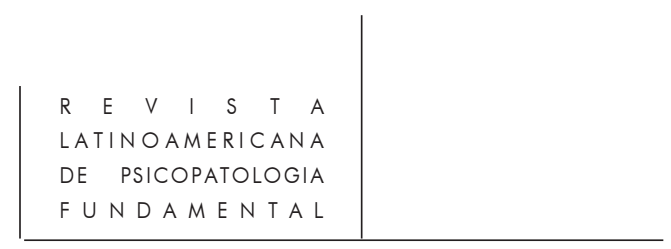

nhuma graça". Dizia também, naquele primeiro encontro, que quando ela era ela mesma, o problema de sua vida era o de comunicação: não sabia como falar com as pessoas, sentia-se numa redoma, num quarto escuro e o melhor seria voltar ao útero materno.

Sempre morou numa vila pobre da cidade, havia terminado o primeiro grau e, por conta de sua inibição e falta de comunicação, não tinha levado adiante os estudos de segundo grau, bem como não conseguia permanecer nos vários empregos como escriturária, pelos quais tinha passado: nunca tinha sido mandada embora; ela se demitia antes por achar tudo aquilo sem graça. Mais tarde vim a saber que Lia havia trabalhado também como doméstica - profissão da mãe - na casa de uma senhora; interrompia o trabalho para ler os livros da biblioteca da casa, até que, por fim, deixa o emprego por não cumprir a função.

Nas entrevistas seguintes, continuou a trazer o gravador; falava muito pouco e grande parte do tempo era dedicado às suas tentativas de ouvir a própria voz. Ora falava na primeira pessoa, ora como a repórter Vassoler. Começou a me falar de outros personagens: ${ }^{4}$ não eram como a Vassoler, que era também ela; eram "pessoas fora dela" que lhe diziam para fazer certas coisas. Havia o Peter, que era um pintor famoso, já de meia-idade, morava nos Estados Unidos e, vez por outra, vinha visitála: ele exigia que ela "levantasse da cama, saísse do quarto, fosse para o mundo lá fora, onde existiam pessoas e não apenas gente sem vida". Às vezes, ele a atormentava tanto com suas exigências, que ela ficava exausta. Considerava Peter seu melhor amigo, a despeito de suas exigências; queria que ela escrevesse, que pintasse e, muitas vezes, ela só queria ficar na cama. Além de Peter, outros personagens, sem muita corporeidade como ele e Vassoler, tomavam conta dela.

Começa, então, a construir um delírio francamente persecutório, cuja temática versava sobre uma rede de computadores que se ligava à sua casa e desta para o mundo todo; sabiam tudo a respeito dela: o que fazia, o que sentia, o que pensava e iriam matá-la. Tudo isto era culpa de uma vizinha que sentia muita inveja dela, das coisas que ela fazia. Uma das vozes que escutava exigia que ela matasse essa vizinha, senão estaria perdida. Peter dizia que ela não devia fazer aquilo, e sim sair de casa, divertir-se e conversar com pessoas, como fazia a Vassoler. Às vezes, seguia seu conselho e a vida ficava maravilhosa novamente.

Devo dizer que fiquei perplexa na primeira entrevista. Intuitivamente, permiti que ela ligasse o gravador e hoje, com o olhar a distância, penso que isso foi o laço inicial que permitiu o andamento do tratamento.

Em função do novo quadro clínico - a franca criação de sintomas psicóticos - foi introduzida, pela psiquiatra que a acompanhava, uma medicação antipsicótica

4. Chamo a estas vozes de "personagens" porque realmente eram personagens de livros que ela havia escrito, como vim a saber mais tarde. 


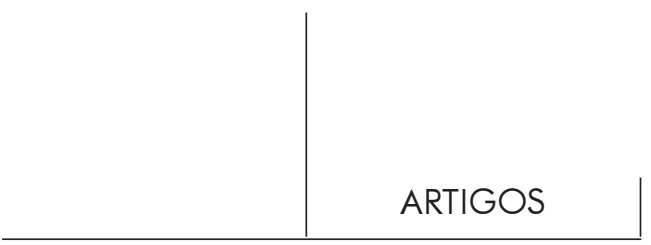

de efeito prolongado e, tempos depois, não havia sinal de seus delírios e as lembranças que tinha daqueles personagens eram apagadas.

A paciente passou a viver uma situação de extrema angústia e de um vazio avassalador, como se antes estivesse diante de um campo florido que, em seguida, fora devastado. Apesar das angústias de seu delírio de perseguição e da sensação contínua de ter seus pensamentos roubados, sentia falta do colorido que lhe davam $P e$ ter e Vassoler. Sua vida não tinha mais sentido e experimentava uma sensação de estranhamento quando contrapunha a vivacidade daqueles acontecimentos e personagens com o irreal que agora lhe restava. Já não mais trazia o gravador para as sessões e começou a faltar com frequiência.

Durante a vivência de seu delírio, os personagens que faziam parte das estórias $^{5}$ escritas por ela saltaram das páginas e tomaram vida real a partir daquilo que a princípio era ficção - Estela Vassoler era um outro dela mesma; Peter, pintor como ela, era quase um alter ego que lhe ditava coisas para fazer; outras vozes a ameaçavam e exigiam a morte da vizinha. Depois da medicação, sua maior angústia era perceber que aqueles personagens não tinham a corporeidade que ela lhes atribuía, que não eram reais e, por não serem reais, não sobreviveram senão como uma vaga e esfumaçada lembrança. Causava-lhe espanto saber que eles não existiam e nem tinham vida própria. Parecia ter sido desafiada pela pergunta paradoxal - para Winnicott, nunca devemos formulá-la a uma criança - e obteve sua resposta angustiante: "Eu criei todos esses personagens (objetos), eles não estavam lá" (não existiam como objetos reais, não os encontrei). No caso de Lia, o objeto não sobreviveu à destruição da fantasia e, como efeito disto, a própria paciente sentiu-se totalmente destruída. Aquilo que até então sobrevivera em sua poesia e em seus contos e estórias, não tinha mais vida para a paciente. Seus escritos continuavam ali, mas já não faziam mais eco para ela, pois seus objetos tinham sido destruídos. A realidade impactante na qual a medicação a lançou, levou-a a não mais reconhecer a materialidade daqueles objetos, de maneira a não poder usá-los nem mesmo como ficcionais personagens de seus escritos.

Não é demais lembrar que a paciente, em sua primeira consulta, trazia como queixa que sua dificuldade era de comunicação. Sua fantasia delirante carecia mesmo de comunicação, talvez por não fazer parte de uma realidade que pudesse ser compartilhada por alguém; enquanto delírio, não resistiu ao impacto da realidade que a medicação lhe impôs. Sua estranheza ao reconhecer que aquele mundo não era real - não estava ali no momento em que foi criado, para falar como Winnicott - leva-a a sentir o mundo como destruído. Nem ela nem seus objetos sobreviveram - naquele

5. A tradição de nossa língua guarda uma diferença sutil entre história e estória, que a gramática moderna, infelizmente, aboliu; gostaria de incorrer no erro gramatical e preservar neste texto essa diferença tão fundamental. 
momento - ao impacto entre a realidade por ela criada e aquela que lhe foi oferecida pós-medicação.

A partir daí, a paciente passou a faltar às consultas e, quando comparecia, permanecia completamente emudecida. Não havia mais nada que tornasse possível, naquele momento, seu vínculo ao tratamento.

Numa das sessões a que compareceu, Lia fizera esforços para entender o que havia se passado e atribuíra à medicação anterior (Parnate) a possibilidade de ter criado todo um mundo particular habitado por "pessoas" imaginárias que, por um certo tempo, passaram a dar sentido a sua vida. Algumas vezes dizia que daria tudo para ter aquelas pessoas de volta. Lembrava-se de que Peter dizia a ela para escrever e pintar, mas não tinha mais razão de ser.

Até este momento eu não sabia da existência de seus escritos. Conhecia seus personagens como ela os apresentara a mim: ora como fazendo parte de seu próprio eu - como quando era a Vassoler - ora como pessoas, fruto de seu delírio. Em uma dessas sessões, posterior ao uso da medicação, fala-me de seus escritos e peço a ela que os traga para que leiamos. Pedi, também, que me falasse das histórias que ela escrevia - até então não sabia da dimensão de sua escrita - e respondeu-me que não sabia falar disto. Fiquei surpresa ao ver diante de mim dois espessos volumes escritos em uma máquina de escrever antiga, permeados de gravuras, desenhos e pinturas. Começamos uma leitura conjunta; depois, ela me pediu para ficar com os livros para podermos falar deles na sessão. Como ela tinha muita dificuldade em falar, pensava, intuitivamente, que seus escritos poderiam ser um meio para poder falar de si. Hoje, penso que eles não são apenas um meio, mas sua forma peculiar de se inscrever no mundo.

De minhas reflexões posteriores, atribuí aos escritos que ela me trazia um substituto daquele laço transferencial inicial - o gravador - e que havia sido perdido depois de sua retirada do delírio. Penso que sua forma de contato com o mundo é feito através da escrita, dos desenhos e pinturas elaborados que faz. Continuo a atendêla e muitas vezes, durante a sessão, quando está "muda, sem voz", é através da escrita que fala.

Não sem um certo receio em me expor demais, devo confessar, também, que as vezes em que tem faltas contínuas, ela se faz presente escrevendo-me cartas, as quais são todas respondidas por mim. Tomo essas cartas como uma substituição, na verdade, uma continuação de sua análise. A singularidade deste atendimento psicanalítico exige a ousadia em expandir o espaço do encontro psicanalítico através das cartas para além daqueles limites da hora marcada da sessão; disso resulta uma certa garantia em não desfazer o laço transferencial de Lia.

Talvez tudo isto soe pouco ortodoxo em relação ao setting analítico; porém, se há desejos sendo mobilizados e se seu inconsciente fala pela porta da escrita, penso que permanecemos, ainda, no terreno da psicanálise. 


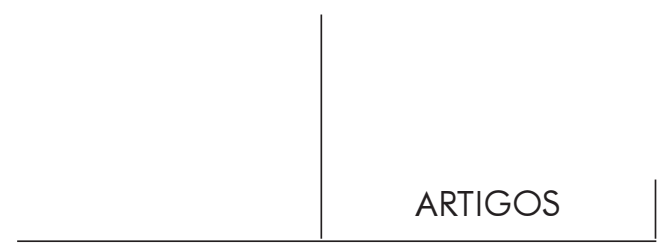

Questões de ordem então eram-me impostas. Em que a psicanálise poderia ajudar na reconstrução de seu mundo que havia sido destruído? Por alguns anos construiu estórias com sua escrita e, através delas, preenchia o vazio de sua própria história. Mas esse solilóquio impresso ao longo do tempo mostrou-se insuficiente como esteio para suas angústias, desamparo e solidão. Ao saltar das páginas, seus personagens criaram para ela - através dela - um mundo muito particular, e essa construção delirante de objetos a impedia - ou ao menos prorrogava - de ficar completamente sem chão e de ser tragada pela destruição. Resgatando Freud, é o delírio como tentativa de cura. Mas esse mundo também se esfarelou sob o efeito da medicação.

Do ponto de vista da psicopatologia clássica, a medicação certeira alivia a paciente de seus sintomas psicóticos que, diga-se de passagem, eram também repletos de sofrimento: eram angustiantes suas idéias delirantes de perseguição, a rede de computadores que a vigiava, a imposição em matar uma vizinha etc. -, mas o reverso disto é a aniquilação total dos objetos por ela criados, correlata à sua própria aniquilação. Se em seu delírio são criados objetos no lugar de algo que não existiu, talvez seja a hora de nos perguntarmos sobre esse algo que não existiu.

A mãe estava no quinto mês de gestação de Lia quando enviuvou. O pai morrera ainda jovem por sequielas do uso de álcool. De acordo com o que ela sabe dessa história, era um homem às vezes violento que às vezes batia na mãe e sua morte trouxe um certo alívio para ela. Esta também exercera, na criação das filhas, vários atos de violência física, em especial contra a irmã mais velha da paciente. Curiosamente, Lia foi a única que escapou dessa violência física. Essas quatro mulheres vivem até hoje numa mesma casa da periferia da cidade e seus laços expressam extrema agressividade nas palavras e nos atos de umas para com as outras. Uma das filhas não permite que a mãe e a paciente façam e nem recebam chamadas telefônicas (o telefone é só da irmã e ninguém pode tocá-lo). A irmã mais velha não compartilha a comida com as outras e mantém sob chaves aquilo que ela compra. Da aposentadoria da mãe (empregada doméstica) é que vem os cuidados materiais (vestir, alimentar etc.) com a paciente. As irmãs, como a mãe, são reticentes e desconfiadas umas das outras; raramente trocam alguma palavra entre si, e, quando isto acontece, é com a marca do rancor. A paciente, mesmo não se relacionando com as irmãs, em alguns momentos diz sentir muita pena delas pela maneira como a mãe sempre as tratou violência física com a primeira e desprezo pela segunda. A mãe, muitas vezes, expressa um desejo declarado de morte para com essas filhas, diz não gostar delas; sente-se abandonada pelas filhas que, agora, revidam as agressividades sofridas.

A mãe me procurou, por duas vezes, para falar de suas preocupações com a paciente e nestas oportunidades tornou explícita essa agressividade para com as filhas. Em relação à paciente, sua preocupação é sempre com a questão material: sua filha não trabalha; a aposentadoria é pequena e ela tem muitas dificuldades em sustentá-la. Acha estranho e muitas vezes não entende as coisas que a paciente faz; 


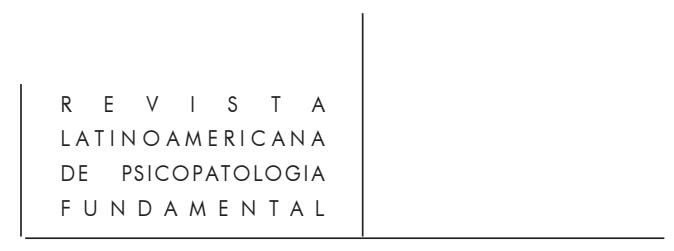

não entende o que ela escreve e acha cansativo ouvir o que escreve. Pareceu-me uma pessoa muito sofrida com a vida - a tarefa de criar as filhas sozinha - e sempre pronta a pedir algum acolhimento material (depois desse encontro, por duas vezes procurou-me para pedir dinheiro para comprar alimentos e me solicitava segredo de seu pedido, cumplicidade que não se efetivou).

Por estranhas razões, as mais velhas - que sofreram a violência explícita da mãe sobre seus corpos - escaparam de algo tão nefasto como a incapacidade de cuidar de si próprias e de trabalhar, como no caso de Lia; não tenho meios, e nem é o objetivo deste trabalho, de dizer se escaparam de outros sofrimentos psíquicos como os que governam a vida de Lia; o que deve ser salientado é que a violência sob a qual Lia foi aprisionada não é a que deixa marcas sobre o corpo, mas na alma.

Lia muitas vezes trazia em seus escritos sua angústia em relação à morte da mãe: "O que será de mim a partir da morte de minha mãe, que já está velha; dependo da mísera aposentadoria dela para viver; acho que será o decreto de minha morte também, pois minhas irmãs não irão cuidar de mim; elas não dão conta nem delas, coitadas."

A angústia da paciente frente à possibilidade da real perda de sua mãe, reedita angústias muito mais antigas cuja tonalidade é dada pela impossibilidade de se construir como um sujeito fora da mãe. As idéias de Winnicott sobre a constituição de um objeto transicional que abarque a criação subjetiva de si, nos ajudam a pensar sobre Lia. Tanto os fenômenos transicionais - uma ponta de um cobertor, uma palavra, uma melodia, um murmúrio - quanto o objeto transicional eleito pela criança constituem barreiras contra a ansiedade, em especial a do tipo depressivo descrita por Melanie Klein. Sua escrita, ainda que não tivesse sido suficiente em si mesma para impedir que Lia desabasse na loucura e ainda que não possa ser nomeada como um objeto transicional por inteiro, é sua tentativa de organizar seu mundo e torná-lo mais suportável.

Em muitos momentos, Lia era mergulhada num vazio muito intenso, pouco falava e, nessas horas, eu the pedia que escrevesse o que sentia. Ela se punha diante da folha em branco e, muitas vezes, ia embora permanecendo a folha sem nenhuma impressão. Outras vezes só falava de seu vazio, da falta de sentido que sua vida tomara depois que não tinha mais seus companheiros de delírio, o que a levava a não ter ânimo para se levantar da cama e viver a vida. Em outras ocasiões, conseguia escrever alguma poesia ou me trazia algo já escrito em sua casa - algum conto que ela escrevera, alguma poesia, algum desenho ou pintura que era sempre acompanhado de algo escrito a respeito.

Winnicott, com a ajuda de seus pacientes, acabava sempre por reinventar a psicanálise. Utilizava, muitas vezes, aquilo que ele chamava de o jogo do rabisco (1979: 32): com uma das crianças, um menino que apresentava intensos temores de separação, rabiscava qualquer tipo de traço e o convidava a transformar esse traço em 


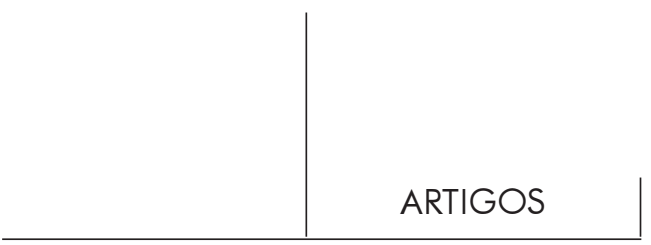

algo; em seguida, a própria criança fazia um traço para que o analista o transformasse e desse alguma materialidade ao rabisco. Isto me faz pensar que essa escrita, esse traço sem ser permeado pela consciência - é quase uma garatuja, sem nenhuma objetivação consciente - e construído à quatro mãos oferece um espaço adequado para a subjetivação do paciente. No caso desse pequeno paciente de Winnicott esses rabiscos revelaram toda a dificuldade dessa criança em suas experiências de separação da mãe (para ter um outro bebê, para uma pequena viagem e uma internação psiquiátrica); seus rabiscos sempre remetiam à imagem gráfica do laço, chicote, cordão, nó etc., traços esses que deixavam a marca do temor da separação.

Ao sugerir a Lia que escrevesse durante as sessões reassegurava não só uma situação transferencial tão difícil de ser estabelecida, mas, além disto, criava um espaço para que suas angústias pudessem ser subjetivadas e que, através de suas estórias e de seus desenhos, pudesse reinventar a si mesma.

Piera Aulagnier nos ajuda muito neste ponto. Para ela, ao nascermos nos ancoramos, idealmente, numa história mítica que, como tal, atravessa nossa própria existência; ${ }^{6}$ essa história é o chão sob o qual nos apoiamos para trilhar nossa própria história. Para o psicótico há uma falha no assentamento e construção dessa história, que o impede de se situar em relação ao mundo no qual está inserido. No lugar de uma terra firme não há senão um pântano movediço que faz tremer a realidade. $\mathrm{Na}$ impossibilidade de ter sua própria história inscrita em si mesma, Lia desenha e escreve histórias; cria personagens com os quais passa a ter uma intimidade tão estreita cujo espaço de segredo7é a única forma, por assim dizer, de pensar e dialogar.

Para Lia, sua escrita é o que dá sentido para sua existência. Ilustrarei aqui, com um trecho de sessão, o significado disto com suas próprias palavras: “A escrita é tudo para mim. Às vezes escrevo à mão, às vezes à máquina; quando escrevo à mão parece um sonho; depois, quando passo para a máquina, me desperto e é uma outra realidade; arrumo aqui e ali. Um amigo do ateliê $\hat{e}^{8}$ disse que viver muito a ficção é perigoso. Viver é perigoso porque a gente morre. Não sei se foi isto que ele quis dizer. Viver a ficção não é perigoso; eu vivo assim. Às vezes converso com as pessoas, as observo, escuto suas conversas e penso: 'Tal palavra poderia ser dito por fulano'. É assim. Eu acho mais interessante a ficção”.

É notável essa distinção entre a escrita manual e a da máquina, pelas conseqüências que, efetivamente, traz para a vida de Lia. Enquanto escreve à mão, vive a

6. Ver segunda parte deste trabalho no qual estas questões teóricas foram apresentadas.

7. Para P. Aulagnier o lugar do segredo é o lugar do pensar: não é possível pensar senão em segredo.

8. Ateliê de pintura do Serviço de Saúde Dr. Cândido Ferreira, antigamente, um hospital psiquiátrico de Campinas cujas mudanças levaram à desospitalização e reintegração dos pacientes à comunidade. Encaminhei Lia a este serviço de saúde mental para que usufruísse das oficinas de literatura e pintura aí oferecidas. 


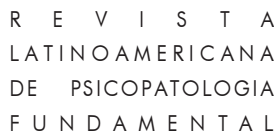

ficção em toda sua radicalidade e realidade de sonho, como o fazemos quando dormimos e sonhamos. A passagem daquilo que está impresso, no papel, por suas mãos a uma impressão elaborada à máquina - arrumo aqui e ali - impõe um distanciamento daquela produção mais imediata que, neste momento de sua vida, a impede de naufragar nas águas tempestuosas da psicose; não que sua produção secundária, à máquina, tenha deixado de ser ficção; é que neste segundo tempo ela sabe, agora, que é uma ficção. Uma ficção que, como toda ficção, não rompe o cordão com aquele outro de todos nós, mas que não faz e não deixa tremer sua realidade. Num certo sentido, paradoxalmente, sua vida é ficção; porém, essa ficção já não se confunde mais consigo mesma: Lia já não mais é tragada pelo sumidouro daquela ficção radical expressa em seu delírio.

É interessante que a fala de seu amigo, que aponta para os perigos da ficção viver a ficção é perigoso porque a gente morre -, não a impressiona. Talvez porque saiba que viver é perigoso de qualquer jeito. Riobaldo via o perigo em viver espalhado por todo sertão. Mas se, por um lado, viver a ficção em sua radicalidade pode ser sinalizado como a última ficha para não morrer, por outro, sinaliza igualmente para aquilo que seu amigo dizia, não da morte real, mas da morte de si expressa no "a gente morre".

É interessante notar o lugar especial que aqueles personagens de seu romance ainda continuam tendo em sua vida. Em uma sessão recente disse: "Estou muito presa aos personagens de 'Contendas tropicais', principalmente os do segundo livro. A Estela Vassoler, o Natan, o Tom que sumiu; não se sabe se ele morreu ou não ou onde é que ele está. Geralmente o escritor termina a obra e esquece seus personagens; mas desses eu não consigo esquecer". Retomo com ela suas palavras "minha vida é a ficção" e lhe digo que ela viveu alguns desses personagens e que eles sobrevivem, agora como ficção, nela.

"É, vivi. A Estela é tão diferente de mim. É expansiva, não é tímida como eu. Faz entrevistas, reportagens".

Eu lhe digo: "Você fez entrevistas como se fosse ela... ela fez entrevistas por você...."

"É verdade. Como pode ser isto? Naquela época passei a ser esses personagens. Até hoje penso muito neles... tenho apego a eles."

Ela volta a comentar, então, que a maioria dos escritores esquece seus personagens; como boa leitora de romances, lembra que, lá pelas tantas em seu Memórias póstumas de Brás Cubas, Machado de Assis ressuscita Rubião, então já um farrapo humano e, pela boca de Brás Cubas, o autor relembra e reconta parte da estória de Quincas Borba. Machado de Assis não esqueceu seu Quincas Borba-Rubião retratado nas lembranças de outro personagem. Não sem razão ela se lembra de Machado de Assis: seu romance Contendas tropicais tem a estrutura de capítulos (até 


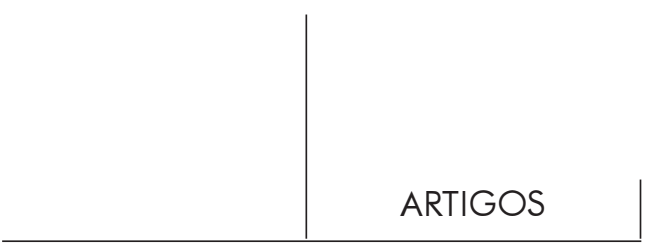

com a numeração em algarismos romanos) e um estilo de escrita que evoca a obra machadiana.

Atualmente, escreve novos contos, poesias e um livro em formato de quadrinhos no qual assina com a marca l'Estaque: "Tenho pensado muito numa nova assinatura: l'Estaque. É meu alter ego. Não acostumei ainda com a sonoridade afrancezada. L'Estaque é uma marca. Só uma marca.” É fundamental ressaltar, mais uma vez, a distância que agora guarda entre sua escrita ficcional e si mesma. Para ela, l'Estaque não é mais que uma marca. L'Estaque é também apenas uma marca para suas produções de desenho e pintura. Seus contos e poesias são assinados com seu próprio nome. A marca L'Estaque, uma mudança sutil do sobrenome materno, transmuta o enigma de seu próprio nome de nascimento. Lia, um de seus nomes fictícios, porta em seu nome de batismo o nome da mãe. Para proteger a identidade da paciente, não posso ir muito adiante no jogo de sentido evocado por seu sobrenome - materno e paterno; posso apenas dizer, valendo-me de sinônimos, que os dois sobrenomes em relação comportam o sentido de "ser impedida de viver"; esta marca enigmática do nome de filiação, cujo "impedimento de viver" é dado pela linhagem materna, condensa a violência fantasmática reproduzida em seu delírio: a rede de computadores roubava seu pensamento - eles sabem tudo o que penso - e via-se aterrorizada por algumas vozes que não lhe permitiam nenhuma outra saída a não ser a morte: ou matar a vizinha ou morrer. A conjugação de seu nome de batismo - sua identidade especular com a mãe - com o sobrenome herdado de pai e mãe resulta em uma mortificação de si própria. Não por acaso, pensar na finitude da mãe era para ela uma experiência avassaladora - quando ela morrer, como vou sobreviver? Vou morrer junto. Numa outra vertente, parte de sua construção delirante visava fazer um recorte entre ela e a mãe: assumir a identidade de um de seus personagens literários - ser Estela Vassoler - lhe garantia viver: saía por aí como "repórter" e não tinha dificuldade de comunicação.

A relação que ela mantém entre seus desenhos e a escrita possui uma pulsação tão original que nos leva a pensar nas relações entre o inconsciente, enquanto imagem pura, e os traços que deixa em nossos sintomas e em nossas falas.

"Agora, aqui no ateliê de pintura, estou muito dividida entre ser artista plástica e ser escritora. Gosto de pintar. Me dá prazer. As pessoas elogiam. Mas quando a pintura é só pintura, não está completa. Tenho que escrever alguma coisa ao lado, escrever uma estória. A pintura, para mim, é um reservatório de imagens que precisa de palavras, que precisam ser escritas depois. Sempre que pinto um desenho tenho necessidade de escrever embaixo ou do lado".

Da pintura e desenho que são imagens que pedem para serem escritas; da escrita à mão para a escrita à máquina, parece haver retranscrições ${ }^{9}$ e rearranjos in-

9. Esta noção de inscrição e retranscrição inconscientes aparece na carta de Freud a Fliess, de 6.12.1896. 


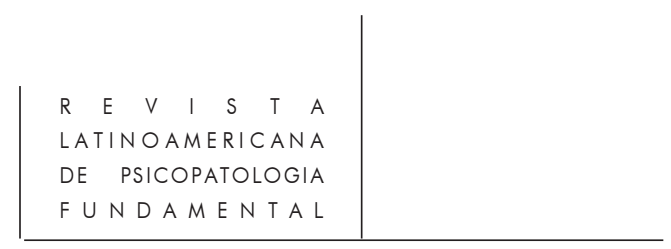

conscientes através dos quais atravessa os enigmas de sua vida e por meio dos quais reinventa sua própria história.

Em um de seus trabalhos com imagem e escrita - uma estória em quadrinhos - Lia retrata a personagem principal em um quarto no qual há uma janela para o mundo onde se inscreve seus devaneios e pensamentos.

Em outro trabalho, um conto em que retrata uma relação não muito tranqüila entre um pintor e um escritor, Lia converte, na fala de seus personagens, a tensão que ela experimenta consigo mesma: "Estou escrevendo um novo conto. É o conto do lago. Está ainda no começo; estou sentindo dificuldade em escrever. Não sei por que não consigo escrever. Penso nos personagens, mas não escrevo. É uma estória sobre um escritor e um pintor. O escritor gosta de pinturas clássicas e o pintor é contemporâneo."

Lia, há alguns meses, disse-me que pretendia se afastar do "Cândido" por um período. Para ela não se trata de um rompimento, mas uma necessidade de ficar um pouco distante em razão de algumas coisas que a chatearam. Aprecia muito a oficina de pintura, porém gostaria de ter encontrado lá uma atenção especial para aquilo que ela escreve. Não foi mais à oficina de literatura. Independente do fato real que a levou a interromper suas idas à oficina de literatura naquele momento (depois ela retoma), algo de singular a move em sua decisão de afastamento: "Se for para escrever sozinha, fico em casa. Se não posso perguntar a ela (pessoa que a orientava na oficina de literatura) sobre a escrita correta de uma palavra estrangeira sem quem ela me devolva a pergunta sem me dizer nada, então escrevo em casa. Esperava mais da oficina de literatura. Gosto da oficina de pintura, gosto das pessoas de lá, do João Bosco, mas não sei... a pintura para mim é um reservatório de imagens que precisa de palavras, que precisam ser descritas depois. Sempre que pinto um desenho tenho necessidade de escrever embaixo ou do lado. E eles não entendem isto. O João Bosco quer que eu vá ao mundo Mix semana que vem; falei que vou, mas não sei. Ele disse que vai sentir minha falta. Devo acreditar?"

Seu afastamento do "Cândido" não poderia ser sinalizado como uma dificuldade de estabelecer vínculos sociais, como já foi em outras situações; nesse momento ela se afastava exatamente por não ter encontrado, na oficina de literatura, um interlocutor que a orientasse em seus escritos; aquilo que ela escrevia já não mais circunvagava em torno de si mesma, não era mais um solilóquio impresso, senão que requeria ouvintes que pudessem escutá-la, opinar sobre o que escreve e reconhecê-la.

\section{Interrogações e considerações finais}

Penso que aquela particularidade de sua forma de escrita, antes de irromper seu delírio, deva ser atribuída a insuficiência de circunscrever sua loucura: seu solilóquio impresso, como me referi por algumas vezes àquela escrita, não visava a nenhum 


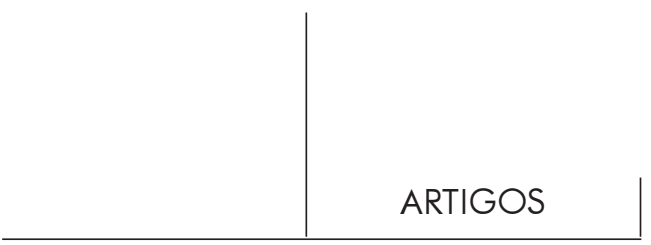

outro além dela mesma; a alteridade existente era aquela que a ficção, tornada real, podia lhe oferecer: a de seus personagens.

Para A. M. Machado (1998), a escrita guarda uma relação estreita com o simbólico. Mas, na psicose, algo escapa a essa regra: o ato de inventar, criar e escrever sobre seus personagens é, sem dúvida, uma tentativa de produzir uma história para si mesma e, pelos efeitos desse ato, também há uma tentativa de simbolização. Contudo, há aí uma questão fundamental a ser formulada: por que o ato em si mesmo da escrita não circunscreveu sua loucura a ponto de torná-la simbólica e metafórica? Por que a "jornalista" Vassoler salta das páginas e, ao invés de ser um alter ego da paciente, passa a ter a corporeidade da própria paciente? E por que, agora, "l'Estaque" não é senão apenas uma marca de cujos limites não se deve ultrapassar, sob pena de Lia se sentir muito incomodada quando, no ateliê, alguém a nomeia como tal? Por que, neste último momento, a ela é possível tomar uma distância de uma marca que é tão ficcional quanto seus antigos personagens e com ela não se confundir? Se a escrita solitária da paciente não foi suficiente para barrar a formação de sintomas psicóticos, qual o estatuto que ela toma na relação da paciente comigo, enquanto sua analista? Sem a escrita seria possível o estabelecimento do vínculo transferencial desta paciente com a analista? Estamos lidando com duas variáveis, as quais são independentes entre si, mas que, na situação específica desta paciente, criam laços indissociáveis a ponto de não podermos falar de uma sem nos aportarmos à outra: a transferência desta paciente só se faz possível nos limites de sua escrita. No entanto, é uma escrita que, mais do que pedir que o olhar de um outro repouse sobre a imagem petrificada no papel, exige que alguém escute sua sonoridade; como as notas musicais impressas que guardam um enigma que só pode ser decifrado pela execução de um e audição de outro; sua escrita espera por um ouvinte.

A situação de escuta psicanalítica parece ter criado condições para que um laço muito peculiar fosse estabelecido entre a paciente e seus escritos e deles para comigo. À medida que traz seus personagens para o palco da análise, ela os retira do confinamento, deixa de figurá-los em seu solilóquio e estabelece, com isto, um laço muito forte que visa o outro. Ao passar a escrever e ler (ou pedir para que eu as lesse) suas histórias nas sessões, algo de interessante passa a acontecer: ela começa a demandar uma certa posição de quem escuta suas histórias; interessa-se - a princípio de maneira incipiente, pois sempre se considerou muito desinteressante e chata para que alguém pudesse ler ou ouvir seus escritos, mas, num crescendo, isso vem a se tornar fundamental para ela - por aquilo que o outro pensa a respeito de seu estilo e de seus personagens: se estão bem caracterizados, qual a marca que é própria a cada um, o que cada um fala de si mesma enquanto autora de seus dias.

É interessante observar que durante muito tempo eu sabia mais da história de seus personagens, tanto dos contos quanto de seus romances, que dela própria. Nesse sentido, é infrutífero, e talvez nefasto, pensar numa história clínica tradicional para 


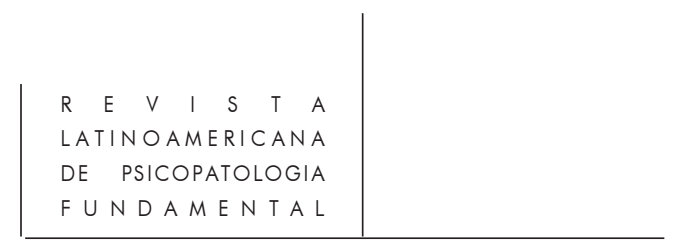

compreender seu "caso clínico". Nessa esfera, não há anamnese a ser feita. Não há aquilo que, para um neurótico, é muitas vezes eficaz, lembranças esquecidas a serem revividas, mas estórias a serem inventadas e reinventadas. Há angústias aterradoras, situações de extrema melancolia, agonias, entretanto, tudo demasiadamente explícito, sem que tivesse havido uma inscrição que fora esquecida e apagada.

Mas, ainda que a escrita de Lia seja o solo no interior do qual sua transferência germina, que espécie de transferência é essa que torna possível o andamento de seu tratamento? Acentuamos que só sua escrita não bastou para que pudesse se inserir no mundo simbólico da cultura a que pertence. Já disse, em outro momento, que Lia é uma paciente especial para mim. A peculiaridade de sua pessoa, de seus desenhos e de seus escritos levou-me a uma situação contratransferencial de reescrever, dentro da formalidade acadêmica, ao desenvolver um projeto de pesquisa, suas próprias estórias e, com ela, criar um espaço de invenção de sua história, de criação de seu próprio mito, naquele sentido que P. Aulagnier sugere.

Para além das transferências de pensamento (Gori, 1998) que regem as associações de nossos pacientes, o pensamento de transferência deve encontrar lugar na situação de análise para que esta tenha andamento. A têmpera desses pensamentos de transferência é dada, como o metal nas mãos de um ferreiro, no espaço analítico, cuja forja é da natureza de um acolhimento daquilo que é dito como significante. Na primeira entrevista, Lia, sonhando ser Vassoler, traz seu velho gravador para me entrevistar; este significante "Vassoler", sem que minha consciência dele se desse conta naquele momento, faz eco enquanto pensamento de transferência que é naquela situação inicial, e vem a criar um ponto de liga para que as afinidades eletivas de transferência e constratransferência pudessem se efetivar. Vassoler ressoa como Vá-sóler e, como tal, engendra um desejo de que aquilo que move sua pena pudesse ser lido e ouvido. É interessante que a marca deste significante tenha tomado a corporeidade da própria paciente: ela se apresentava como Vassoler e endereçava este significante, num certo sentido, visual, a quem estava diante dela para ser "entrevistada". Entre vistas (minha e dela), ela se colocava como Vassoler. Nesta franca eclosão de sua psicose, seu desejo se presentificava como o próprio significante (Vassoler), porém, ainda descarnado de uma significação simbólica, pois Lia passava ao largo de um deslize de fala e, de forma peculiar à psicose, como Freud bem definiu ao dizer que aí as palavras são tomadas como representação de coisa, apresentava-se na concretude corpórea de Vassoler.

Sua transferência, neste momento inaugural do tratamento, só se fez possível no interior da singularidade de seus sintomas psicóticos: é como significante puro, destituído de qualquer metáfora que poderia simbolizar suas angústias, que Lia se apresenta e se enlaça na análise. Neste ponto de minhas observações são significativas as palavras de Gori (1998) a respeito da peculiaridade do tratamento com psicóticos em relação àquele da neurose: 


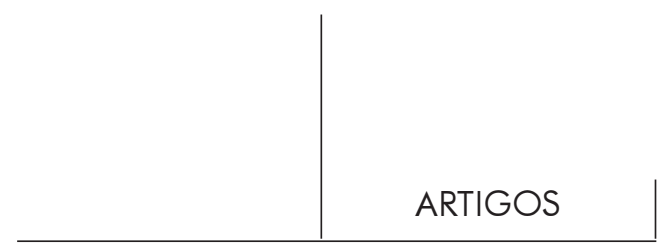

E quando a psicose nos defronta com esse desprendimento da significação em benefício do significante, como, por exemplo, na esquizofrenia, mudamos de regime psíquico e o paradigma de nosso trabalho psicanalítico encontra um limite incontornável. Assim, parece, como dizia Perrier, que o que surge como ponto de chegada no trabalho psicanalítico com os neuróticos se impõe como ponto de partida da psicose e, por isso mesmo, escapa ao analisável de uma transferência freudianamente constituída. (p. 31)

Resta ainda dizer algumas palavras sobre aquilo que foi se apresentando como norte do tratamento ainda em andamento desta paciente: sua necessidade em falar daquilo que escrevia. Se, antes, sua escrita tinha a marca da solidão, à medida que o tratamento começa a se efetivar, o ato de falar sobre seus personagens passa a ser fundamental para ela. Se, por um lado, sua escrita foi fundamental para o enlace terapêutico, por outro, ela mesma parece demandar a escuta de um outro.

Além de uma pesquisa que sustente a escrita como suporte para a transferência desta paciente, pretendo, pela situação de interlocução privilegiada(ibid., p. 100) que a psicanálise convoca direcionar esta pesquisa para relações fundamentais entre sua escrita literária como alteridade para si mesma e sua fala sobre esta mesma escrita como condição para o tratamento.

Por um longo período sua escrita solitária - seu solilóquio impresso - foi a única forma possível de manter-se inteira; no entanto, ao não encontrar ressonância daquilo que escrevia em nenhum outro fora dela mesma - não por acaso dizia que seu problema era de comunicação - passa a dar existência real àquilo que, até então, era apenas ficção: a alteridade possível era aquela que a ficção, tornada realidade, podia lhe oferecer: a de seus personagens. Essa alteridade possível era sua tentativa de cura; na ausência de um outro que pudesse ser suporte de simbolização, Lia criava seus próprios outros em seu delírio.

Seu tratamento passa a ser possível em torno de sua escrita: a transferência desta paciente só se faz possível nos limites de sua escrita. É através dela que o Outro, do real de sua ficção, migra para o simbólico desta mesma ficção.

\section{Referências bibliográficas}

Aulagnier, P. O aprendiz de historiador e o mestre-feiticeiro. Do discurso identificante ao discurso delirante. São Paulo: Escuta, 1989.

Gori, R. A prova pela fala. Sobre a causalidade em psicanálise. São Paulo: Escuta, 1998. Goethe, J. W. Memórias: poesia e verdade. Brasília: UNB/Hucitec, 1986.

Machado, A.M.N. Presença e implicações da escrita na obra de Jacques Lacan. Ijui: Unijuí, 1998.

Manguel, A No bosque do espelho. São Paulo: Companhia das Letras, 2000. 
Masson, J.M. (ed.). A correspondência completa de S. Freud para W. Fliess -1887-1904. Rio de Janeiro: Imago, 1986.

WinnicotT, D.W. O brincar e a realidade. Rio de Janeiro: Imago, 1979.

\section{Resumos}

La singularidad de una escucha psicoanalitica con pacientes psicoticos exige de quien se dispone a trabajar con eses pacientes un depojamiento que visa ultrapasar los límites de una transferencia, a la primera vista, incontornable. Es presentado aquí el manejo transferencial a traves de la escrita de una paciente psicotica y algunas reflexiones sobre la expanción del espacio psicoanalitico que la clinica con psicoticos demanda.

Palabras llave: Psicoanálisis, psicosis, transferencia, literatura

La singularité de l'écoute psychanalytique avec des patients psychotiques exige de la part de celui qui se dispose à travailler avec ces patients une attitude de renoncement qui vise à dépasser les limites d'un transfert à première vue incontournable. Il est présenté ici un maniement du transfert à partir de l'écriture d'une paciente psychotique, ainsi que quelques réflexions sur l'expansion de l'espace psychanalytique que la clinique avec les psychotiques sollicite.

Mots clés: Psychanalyse, psychose, transfert, littérature

The singularity of psychoanalytic listening with psychotic patients requires of the professionals who are willing to work with this class of patients a level of detachment that goes beyond the limits of the transference, and such detachment may at first seem unreachable. The management of the transference through the writings of a female psychoanalytic patient is described here, as well as a discussion on the expansion of the psychoanalytic space that clinical work with psychotic patients may require.

Key words: Psychoanalysis, psychosis, transference, literature

Versão inicial recebida em fevereiro de 2001

Versão revisada recebida em agosto de 2001 